\title{
EXPERIMENTAL RESULTS OF DAMAGED RC BEAMS
}

\author{
Lviv Polytechnic National University, \\ Department of highways and bridges \\ yaroslav.z.blikharskyy@lpnu.ua
}

(C) Blikharskyy Ya. 2021

This article presents the results of an experimental study of damaged reinforced concrete beams. Corrosion of reinforcement in concrete is one of the main problems of durability faced in practice by civil engineers. Particular attention should be paid to the action of an aggressive environment as one of the most common causes of the introduction of elements into an emergency. The aim of the work is to determine the strength and deformability of reinforced concrete structures without damaging the reinforcement and in case of damage. According to the research program 4 beams were tested. Among them were undamaged control samples with single reinforcement of $\varnothing 20 \mathrm{~mm}$ diameter and samples with $\emptyset 20 \mathrm{~mm}$ reinforcement with damages about $40 \%$. The reinforcement was damaged before concreting the samples. The test specimens were tested for bending under short-term load. At the result impact of damage to reinforcement in $\mathrm{RC}$ beams reduces the load-bearing capacity. The results are given in the article.

Key words: reinforced concrete beams, real size, experimental researching, damaged reinforced concrete structures, damaged reinforcement, load-bearing capacity.

\section{Introduction}

Reinforced concrete structures are among the most common all over the world (Azizov et al., 2019, Algburi et al., 2019, Pavlikov et al., 2018, Kramarchuk et al., 2020). However, under the influence of time, the environment, low-quality materials, their performance properties were determinate. The operation of reinforced concrete structures of buildings and structures often takes place in an aggressive environment. This applies to most industrial buildings, especially those with chemical production, open environments, marine coastal structures, and so on. The action of aggressive environments causes corrosion of concrete and reinforcement of structures. This, as a consequence, reduces their load-bearing capacity and serviceability. The most favorable conditions for corrosion of reinforced concrete structures occur in the chemical industry. Chemically active substances, aggressive to reinforced concrete structures, occur both directly in the production processes and in the environment due to the failure of process equipment, harmful emissions into the atmosphere. That is why reinforced concrete structures with damaged reinforcement are an urgent issue. It is important to study such structures and take into account all the factors influencing the damage to the reinforcement of these structures.

\section{Review of scientific sources and publications}

Damage to individual elements of reinforced concrete constructions is caused by various groups of influences (Tayeh et al., 2019, Kos et al., 2019, Vavrus et al., 2019): technological factors (inaccurate placement of reinforcement, damage to elements due to construction and installation operations and transportation, violation of design parameters in the manufacture of reinforced concrete elements of nonstandard configuration). (changes in the stress-strain state of the element due to violation of their design position and the calculated external influences). Particular attention should be paid to the action of an 
aggressive environment as one of the most common causes of the introduction of elements into an emergency. Corrosion of reinforcement in concrete is one of the main problems of durability faced in practice by civil engineers (Dmitrovic et al., 2019, Goyal et al., 2018, Vavrus et al., 2015). In (Giorgio et al., 2019), longitudinal controlled ultrasonic waves were used to monitor ulcerative and initial defects in steel rods in reinforced concrete structures, which mimics the phenomena of fading and delimitation caused by corrosion. Two ultrasonic techniques (pulse and pulse-echo transmission) were used to monitor the whole and damaged sample. The developed technique is successfully used for real-time monitoring of reinforcement of reinforced concrete samples that undergo accelerated corrosion. Corrosion of steel in reinforced concrete leads to several major disadvantages. First, the reduction of the transverse sectional zone of reinforcement and its ductility leads to premature violation of elasticity. Secondly, the expansion of corrosion products causes concrete cracking and damage to the connection between concrete and reinforcement, as well as affects the stiffness of bent reinforced concrete elements, which reduces the overall load-bearing capacity of reinforced concrete beams.

The current normative documents (Bambura et al., 2018, Karpiuk et al., 2020) regulate the calculation of the bearing capacity of the damaged element by approximating its cross-section to a certain equivalent, but it should be noted that the use of such an approach has a significant impact on the nature of the damage. A detailed classification of possible damage to reinforced concrete elements, the reasons for their occurrence and features of the development are given in (Cigada and Zappa, 2014, Kotesa et al., 2015).

However, the effect of changes in the physical and mechanical characteristics of reinforcement in reinforced concrete structures has not been sufficiently studied. That is why the topical issue is the implementation of experimental studies of such constructions.

\section{The aims and objectives of the study}

The aim of the work is to determine the strength and deformability of reinforced concrete structures without damaging the reinforcement and in case of damage. To determine the impact of reduce of bearing-capacity in damaged beams.

\section{Materials and methods}

According to the research program 4 beams were tested. Among them were undamaged control samples with single reinforcement of $\varnothing 20 \mathrm{~mm}$ diameter - BC-1 and BC-2; samples with $\emptyset 20 \mathrm{~mm}$ reinforcement with damages about $40 \%$ with changes in the physical and mechanical properties of reinforcement - BD-3 and BD-4. The reinforcement was damaged before concreting the samples.

The reinforcement of samples: A500C steel bars, the diameter was $\varnothing 20 \mathrm{~mm}$. Reinforcement of compressed zone and transverse reinforcement are made of $\varnothing 5$ B 500 bars. Transverse reinforcement $\varnothing 5$ B500C has $75 \mathrm{~mm}$ spacing (Fig. 1).

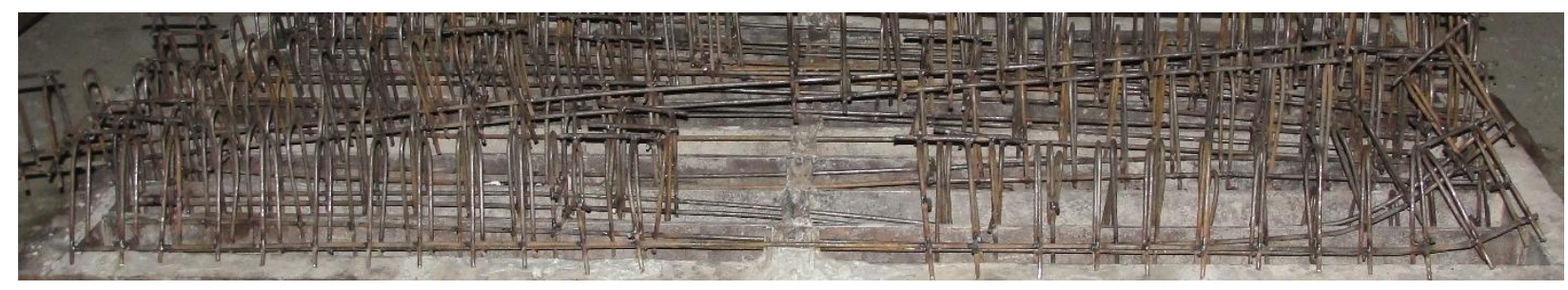

Fig. 1. The general view of reinforcement

Experimental samples used in the research had the length of $2100 \mathrm{~mm}, 100 \mathrm{~mm}$ weight, and $200 \mathrm{~mm}$ height. The beams` concrete composition: $\mathrm{C}$ : $\mathrm{S}: \mathrm{R}=1: 1.16: 2.5$ with $\mathrm{W} / \mathrm{C}=0.375$. The cement used $-\mathrm{M}-500$, sand quartz without impurities with a size module $\mathrm{M}_{\mathrm{k}}=2.00$, granite rubble of fractions $5-10 \mathrm{~mm}-66 \%$, 
$10-20 \mathrm{~mm}-33 \%$. The remarkable aspects and specifics of the reinforcement material degradation are presented on the basis of particular samples with predetermined material properties. The samples are thermally $\varnothing 20 \mathrm{~mm}$ A500C steel bars. The attention should be paid to specific non-uniform properties of the modeled samples, described in the previous study (Blikharskyy, 2019).

The test specimens were tested for bending under short-term load. The load level was monitored by means of annular dynamometers, which simultaneously served as a hinged support on one side and a fixed support on the other side of the beam with a run of $1900 \mathrm{~mm}$. The load was applied in the form of two concentrated forces in the thirds of the span of the beam by means of a hydraulic jack and a distribution traverse (Fig. 2).

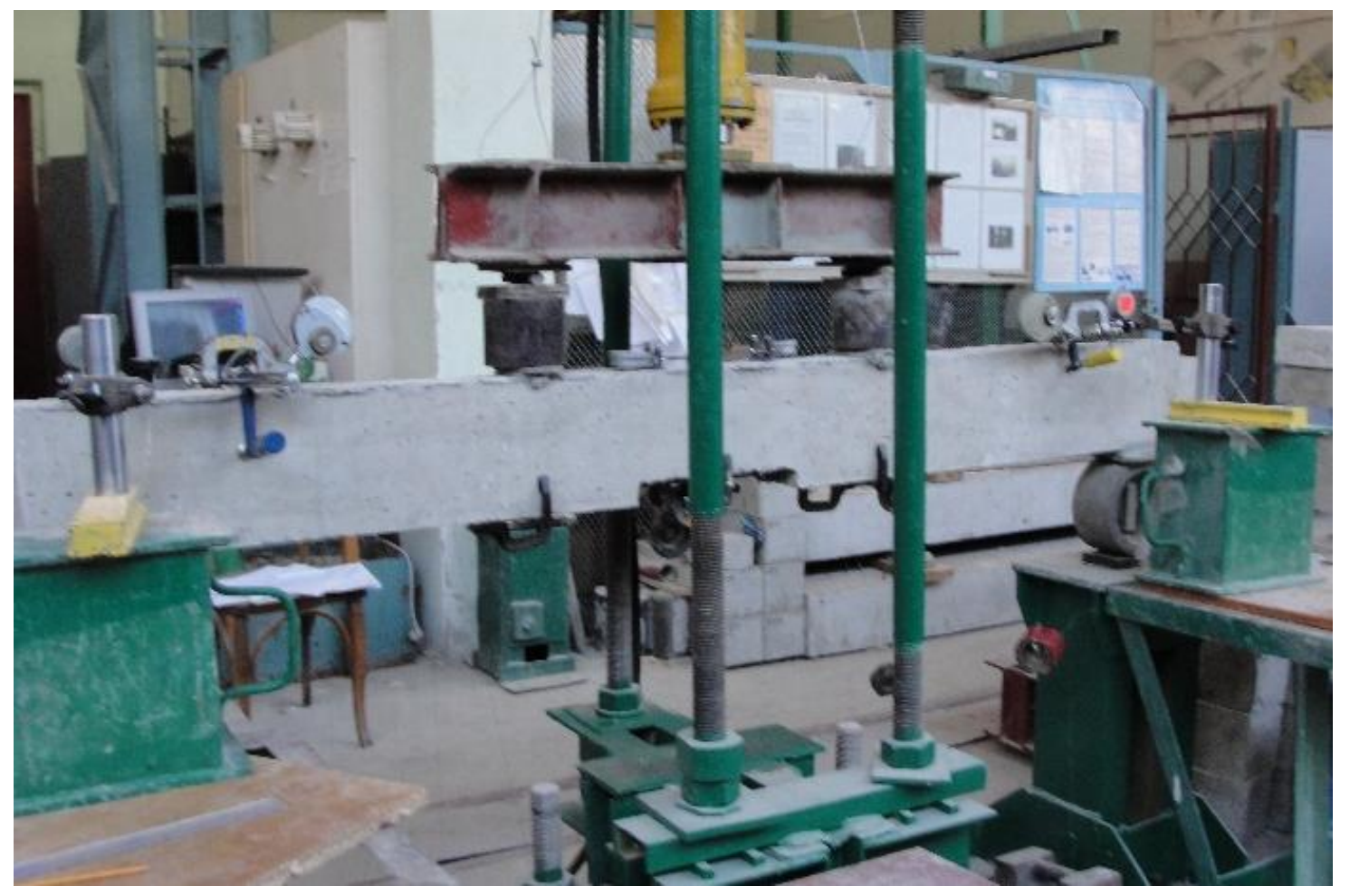

Fig. 2. The graphs of the strains' calculated values of the stretched main steel rebar's (stretched reinforcement) and the compressed concrete (compressed concrete) for beam BD-2

Deformations of reinforcement and compressed concrete were measured using clock-type micro indicators with a division price of $0.001 \mathrm{~mm}$. Five deflection gauges were installed on the beam to measure the deflections.

The load was applied in stages of $5 \%$ until the first cracks with a holding time of 15 minutes After each condition, which mainly corresponded to a bending moment of $30 \%$. After that, the load was continued in steps of $10 \%$ for 15 minutes after each step. Exposure was performed to stabilize the plastic deformations of concrete. For the first 10 minutes, the appearance of new cracks, the development of previous cracks were monitored, and the width of their opening was measured using a $\mathrm{BCH}-2$ microscope. The price of the division of a microscope is $0.05 \mathrm{~mm}$. On the side-free side of the beams, the cracks were numbered in turn and their cracks were sketched, indicating the corresponding stages of loading. The next 5 minutes recorded the readings of micro indicators and deflect gauges.

\section{Results and discussions}

In the beam BC-1, according to the experimental results, the moment which corresponds to the limit strain of the reinforcement was at $M_{S, y}^{\exp }=25.8 \mathrm{kNm}$, further loading was accompanied by the 
significant increase in the strain of the reinforcement and concrete. The load at which the compressed concrete reached the limit strain was at $M_{\text {ult }}^{\exp }=27.2 \mathrm{kNm}$.

For the BC-2 the moment which corresponds to the limit strain of the reinforcement was at $M_{S, y}^{e x p}=24.1 \mathrm{kNm}$. The load at which the compressed concrete reached the limit strain was $M_{\text {ult }}^{\text {exp }}=26.1 \mathrm{kNm}$.

In the beam BD-3, according to the experimental results, the moment which corresponds to the limit strain of the reinforcement was at $M_{S, y}^{e x p}=15.4 \mathrm{kNm}$. The load at which the compressed concrete reached the limit strain was $M_{\text {ult }}^{\exp }=16.7 \mathrm{kNm}$.

In the beam BD-4, according to the experimental tests, the load at which the deformation of the main rebar reached the yield strength was $M_{S, y}^{\exp }=15.9 \mathrm{kNm}$. The load at which the compressed concrete reached the limit strain was $M_{u l t}^{\exp }=17.7 \mathrm{kNm}$.

Table 2

Bearing capacity of beams

\begin{tabular}{|c|c|c|c|c|c|c|}
\hline $\begin{array}{c}\text { Sample } \\
\text { mark }\end{array}$ & $\begin{array}{l}\text { Moment which } \\
\text { corresponds to the limit } \\
\text { strain of the } \\
\text { reinforcement, } \mathrm{kNm}\end{array}$ & avarage & $\begin{array}{l}\text { Deviation in } \\
\text { the bearing } \\
\text { capacity } \\
\text { values, \% }\end{array}$ & $\begin{array}{l}\text { Moment which } \\
\text { corresponds to the } \\
\text { limit strain of the } \\
\text { concrete, } \\
\text { kNm }\end{array}$ & avarage & $\begin{array}{c}\text { Deviation } \\
\text { in physical } \\
\text { destruction, } \\
\%\end{array}$ \\
\hline BC-1 & 25.8 & \multirow{2}{*}{24.95} & \multirow{2}{*}{-} & 27.2 & \multirow{2}{*}{26.65} & \multirow{2}{*}{-} \\
\hline BC-2 & 24.1 & & & 26.1 & & \\
\hline BD-3 & 15.4 & \multirow{2}{*}{15.65} & \multirow{2}{*}{37.27} & 17.1 & \multirow{2}{*}{16.9} & \multirow{2}{*}{36.58} \\
\hline BD-4 & 15.9 & & & 16.7 & & \\
\hline
\end{tabular}

The impact of damage to reinforcement in RC beams reduces the load-bearing capacity. The deviation between damaged and undamaged specimens of the bearing capacity for the moment which corresponds to the limit strain of the reinforcement was $37.27 \%$. This value for the moment which corresponds to the limit strain of the concrete was $36.58 \%$.

\section{Conclusion}

Damage to the thermally reinforced layer of reinforcement of RC beams significantly affects the reduction of load-bearing capacity. When the reinforcement is damaged by $40 \%$, the bearing capacity is reduced to $36-37 \%$. Therefore, these experimental studies need to be considered about the examination of damaged reinforced concrete constructions.

\section{References}

Algburi, A. H., Sheikh, M. N. and Hadi, M. N. (2019). Analytical investigation on the behavior of circular and square RC columns strengthened with RPC and wrapped with FRP under uniaxial compression. Journal of Building Engineering 25, 100833.

Azizov, T. N., Kochkarev, D. V. and Galinska, T. A. (2019). New design concepts for strengthening of continuous reinforced-concrete beams. IOP Conference Series: Materials Science and Engineering 708 (1), 012040. https://doi.org/10.1088/1757-899X/708/1/012040 
Bambura, A. M., Dorogova, O. V., Sazonova, I. R., and Bogdan, V. M. (2018). Calculations of the eccentriccompressed slender reinforced concrete members applying an "effective" curvature method. Nauka $i$ budivnictvo, (3), 10-20. [In Ukranian].

Blikharskyi, Y. Z. (2019). Anisotropy of the Mechanical Properties of Thermally Hardened A500s Reinforcement, Mater Sci 55, 175-180. https://doi.org/10.1007/s11003-019-00285-0

Cigada, A. and Zappa E.. (2014). Vision device applied to damage identification in civil engineer structures, Structural Health Monitoring 5, 195-206.

Dmitrovic, L. G. Z., Kos, Z., and Klimenko, Y. (2019). The Development of Prediction Model for Failure Force of Damaged Reinforced-Concrete Slender Columns. Tehnički vjesnik 26 (6), 093612. https://doi.org/10.17559/TV20181219093612

Giorgio, B, Cigada, A. and Zappa E. (2014). Vision device applied to damage identification in civil engineer structures, Structural Health Monitoring 5, 195-206. https://doi.org/10.1007/978-3-319-04570-2_22

Goyal, A., Pouya, H.S., Ganjiam, E. and Claisse P. (2018). A review of corrosion and protection of steel in concrete. Arabian Journal for Science and Engineering 43, 5035-5055. https://doi.org/10.1007/s13369-018-3303-2

Karpiuk, V., Somina, Y. and Maistrenko, O. (2020). Engineering Method of Calculation of Beam Structures Inclined Sections Based on the Fatigue Fracture Model. LNCE 47, 135-144.

Kos, Z. and Klimenko, Y. (2019). The Development of Prediction Model for Failure Force of Damaged Reinforced-Concrete Slender Columns. Tehnički vjesnik 26 (6), 1635-1641. https://doi.org/10.17559/TV20181219093612

Kotesa, P., Brodnana, M., Ivaskovab, M. and Dubalac K. (2015). Influence of reinforcement corrosion on shear resistance of RC bridge girder subjected to shear. Procedia Engineering 111, 444-449.

Kramarchuk, A., Ilnytskyy, B., Bobalo, T and Lytvyniak, O. (2020). The Research Bearing Capacity of Crane Beams for Possible Establishment of Bridge Crane on Them. LNCE 47, 202-210.

Pavlikov, M. Kosior-Kazberuk and Harkava, O. (2018). Experimental testing results of reinforced concrete beams under biaxial bending. IJST, 7(3.2) (2018), 299-305. 10.14419/ijet.v7i3.2.14423

Tayeh, B. A., Naja, M. A., Shihada, S and Arafa, M. (2019). Repairing and strengthening of damaged RC columns using thin concrete jacketing. Advances in Civil Engineering, 2987412. https://doi.org/ $10.1155 / 2019 / 2987412$

Vavrus M. and Kotes, P. (2019). Numerical comparison of concrete columns strengthened with layer of fiber concrete and reinforced concrete. Transportation Research Procedia 40, 920-926. https://doi.org/ 10.1016/j.trpro.2019.07.129

\section{Я. З. Бліхарський}

Національний університет “Львівська політехніка", кафедра автомобільних доріг та мостів

\section{РОЗРАХУНОК ЗА ДЕФОРМАЦЙНОЮ МОДЕЛЛЮ ЗАЛІЗОБЕТОННИХ КОНСТРУКЦЙ 3 ПОШКОДЖЕННЯМИ}

(C) Бліхарський Я. 3., 2020

Наведено результати експериментального дослідження пошкоджених залізобетонних балок. Корозія арматури в бетоні - одна з основних проблем довговічності, з якою стикаються на практиці будівельні інженери. Пошкодження окремих елементів залізобетонних конструкцій спричинене різними групами впливів: технологічними факторами (неточне розміщення арматури, пошкодження елементів внаслідок будівельно-монтажних операцій та транспортування, порушення проектних параметрів під час виготовлення залізобетонних елементів - не-стандартна конфігурація, зміни напружено-деформованого стану елемента внаслідок порушення їх конструктивного положення та розрахункових зовнішніх впливів). Особливу увагу необхідно приділити дії агресивного середовища як одній з найпоширеніших причин введення елементів у непридатні для експлуатації або в аварійному стані конструкцію. Метою роботи є визначення несучої здатності залізобетонних конструкцій без 
пошкодження та 3 пошкодженням робочої арматури. Відповідно до програми досліджень випробувано чотири залізобетонні балки розміром 100×200×2100 мм. Серед них були два непошкоджені контрольні зразки з одинарною арматурою діаметром 20 мм - BC-1 та ВС-2 та два зразки з арматурою $\emptyset 20$ мм із пошкодженнями близько $40 \%$ робочої арматури - BD-3 та BD-4. Арматура була пошкоджена до бетонування зразків. Зразки випробовували на згин за короткочасного навантаження. Рівень навантаження контролювали за допомогою кільцевих динамометрів, які одночасно слугували шарнірною опорою з одного боку і нерухомою опорою з іншого боку балки з прольотом 1900 мм. В результаті вплив пошкодження арматури в залізобетонних балках зменшує їх несучу здатність. Пошкодження термічно зміцненого шару армування впливають на характер руйнування та зменшення несучої здатності, оскільки в робочій арматурі змінюються фізико-механічні характеристики.

Ключові слова: залізобетонні балки, натурного розміру зразки, експериментальні дослідження, пошкодження робочої арматури, несуча здатність. 